\title{
PHYSIOLOGICAL MATURATION IN SEEDS OF SWEET SOGHUM FOR FOLIAR FERTILISATION WITH SILICATE ${ }^{1}$
}

\author{
BRUNO FRANÇA DA TRINDADE LESSA ${ }^{2 *}$, ALEK SANDRO DUTRA ${ }^{3}$, TATIANA MARIA DA SILVA ${ }^{3}$, CAMILA \\ CASTRO SANTOS ${ }^{3}$, WESLEY DO NASCIMENTO SOUSA ${ }^{3}$
}

\begin{abstract}
The aim of this study was to evaluate physiological quality in seeds of sweet sorghum grown under semi-arid conditions, and to determine the age of physiological maturity of the seeds as a function of the foliar application of potassium silicate. The experiment was carried out at the Curu Valley Experimental Farm, in Pentecoste in the state of Ceará, during the rainy seasons of 2014 and 2015. The BRS 506 and BRS 511 varieties were used, under foliar fertilisation with potassium silicate at doses of 500, 1000 and $1500 \mathrm{~mL} . \mathrm{ha}^{-1}$, in addition to the control lots (with no application); harvesting was at four periods, 30, 37, 44 and 51 days after full bloom (DAB). The percentage and speed of germination were evaluated, together with the accelerated ageing test and seedling growth. The seeds presented greater than $90 \%$ germination from $37 \mathrm{DAB}$, reaching high seedling vigour at $51 \mathrm{DAB}$. Foliar fertilisation with potassium silicate under the conditions of the experiment resulted in an increase in the physiological quality of the seeds. The BRS 506 and BRS 511 cultivars displayed the highest physiological quality between 49 and 53 DAF.
\end{abstract}

Keywords: Sorghum bicolor. Germination. Vigour.

\section{MATURAÇÃO FISIOLÓGICA DE SEMENTES DE SORGO SACARINO NO SEMIÁRIDO EM FUNÇÃO DA ADUBAÇÃO FOLIAR SILICATADA}

RESUMO - O objetivo deste trabalho foi avaliar a qualidade fisiológica das sementes de sorgo sacarino cultivado em condição semiárida, procurando-se determinar a época de maturidade fisiológica das sementes em função da aplicação foliar com silicato de potássio. O experimento foi conduzido na Fazenda Experimental Vale do Curu, Pentecoste - CE no período de chuvas dos anos de 2014 e 2015. Utilizaram-se as variedades BRS 506 e BRS 511 sob adubação foliar com silicato de potássio nas doses 500; 1000 e $1500 \mathrm{~mL}^{-h^{-1}}$, além das parcelas controle (sem aplicação) e com colheita realizada em quatro épocas $(30,37,44$ e 51 dias após a plena floração (DAF)). Foram avaliados as porcentagens e velocidade de germinação, o teste de envelhecimento acelerado e o crescimento de plântulas. As sementes obtiveram germinação acima de $90 \%$ a partir dos 37 dias DAF, atingindo alto vigor de plântulas aos 51 dias APF. A adubação foliar com silicato de potássio nas condições aplicadas promoveu acréscimo na qualidade fisiológica das sementes. As cultivares BRS 506 e BRS 511 apresentam o máximo de qualidade fisiológica entre 49 e 53 dias DAF.

Palavras-chave: Sorghum bicolor. Germinação. Vigor.

\footnotetext{
*Corresponding author

${ }^{1}$ Received for publication in $08 / 29 / 2016$; accepted in $12 / 03 / 2016$.

Paper extracted from the doctoral thesis of the first author.

${ }^{2}$ Agricultural Engineering Collegiality, Universidade Federal do Vale do São Francisco, Petrolina, PE, Brazil; bruno.ftlessa@univasf.edu.br.

${ }^{3}$ Department of Plant Science, Universidade Federal do Ceará, Fortaleza, CE, Brazil; alekdutra@ufc.br, tatianad.silva@hotmail.com, camilacastro30@hotmail.com,sds.wesley@hotmail.com.
} 


\section{INTRODUCTION}

Sorghum (Sorghum bicolor (L.) Moench) is used as feedstock in the production of first-generation ethyl alcohol (ethanol), both in small distilleries and in large factories during the sugarcane off-season (RATNAVATHI et al., 2011; MAY et al., 2012). This type of sorghum, despite having lower technological indices compared to sugarcane, the main raw material for the domestic sugar and alcohol industry, has a shorter cycle, of between 100 and 130 days; is propagated by seeds, which facilitates mechanised planting of the crop; and has significant resistance to water scarcity (BLUM, 2004; MAY et al., 2012; GIACOMINI et al., 2013).

The development of techniques and strategies that enable strengthening of agricultural activities in the semi-arid regions of the Northeast are fundamental for the social and economic growth of the region, lessening the effects of such negative factors as the rural exodus and disorderly use of the natural resources of the Caatinga biome. Therefore, the use of plant species and/or genotypes adapted to the climatic conditions of the region, coupled with forms of management that ease the stress caused by the lack of water or excessive sunshine, becomes the key to progress in the region.

Monocot species are known to respond well to silicate fertilisation. These plants have the capacity to accumulate this mineral in leaf and stem tissue (SOUSA et al., 2013; HAYNES, 2014), promoting indirect beneficial effects, such as resistance to pests, diseases, water scarcity and lodging, and better photosynthetic conditioning, as already demonstrated in sugarcane, maize, rice and grain sorghum (PEREIRA et al., 2004; BARBOSA et al., 2008; SOUSA et al., 2010; SOUSA; KORNDÖRFER; WANGEN, 2010).

The foliar application of silicate fertilisers seems to act primarily to assist plants in their protection against biotic or abiotic damage. In this way, expending energy is better utilised for primary metabolism, such as in the accumulation and allocation of photoassimilates (SOUSA; KORNDÖRFER; WANGEN, 2010), which may have an effect on stem maturation and/or panicle development.

According to the above-mentioned characteristics of sweet sorghum, one important evaluation to be carried out is the maturation and viability of the seeds produced in semiarid regions. Small farmers, the majority in this region, harvest the seeds from a part of their own crop for use in the following cycle/year. It is known that to eliminate the possibility of faults in the crop stand, or the emergence of plants of low vigour, it is essential to use seeds with a high level of quality (MARCOS
FILHO, 2015).

Seed maturation consists of an orderly sequence of various different types of change, verified from fertilisation until the seeds become independent of the parent plant (MARCOS FILHO, 2015). The main technological indices desired at the end of maturation are an adequate water content, higher dry matter content, high germination percentage and high level of vigour (ARAÚJO et al., 2006; MARCOS FILHO, 2015).

There are few studies in the literature that focus on the production of sweet sorghum, and investigate the techniques that would favour its management in semi-arid regions; and when the subject is seed production, even less is reported scientifically. The aim of this study therefore, was to evaluate quality in the seeds of sweet sorghum produced under semi-arid conditions, and to determine the age of physiological maturity and the effects on the seeds as a function of the foliar application of potassium silicate.

\section{MATERIAL AND METHODS}

The experiment was carried out from March to July of 2014 and 2015, under rainfed conditions at the Curu Valley Experimental Farm, of the Federal University of Ceará, at Pentecoste in the state of Ceará (CE), at UTM coordinates 462620 E, $9577349 \mathrm{~S}$ and an altitude of $48 \mathrm{~m}$, in a haplic Luvisol of a sandy loam texture. The climate in the region according to the Köppen classification, is BSw'h', i.e. semi-arid with irregular rainfall. Meteorological data for the experimental periods are shown in Figure 1.

After preparing the soil (two harrowings - 2014, one subsoiling and two harrowings - 2015), two varieties of sweet sorghum were planted under rainfed cultivation: BRS 506 (purchased from Embrapa Produtos e Mercado in Sete Lagoas, in the state of Minas Grais) and BRS 511 (made available by Ceres Sementes do Brasil $L t d a$ ). The first is among the most traditional genotypes for the production of ethanol (EMBRAPA, 2012a), while the second is a more recently developed cultivar with higher technological indices for stem production (EMBRAPA, 2012b). Sowing took place on 03/22/2014 (first cycle) and 03/07/2015 (second cycle).

Considering the soil analysis (Table 1) and the recommendations of Coelho (2012), fertilisation with 30,50 and $45 \mathrm{~kg} \mathrm{ha}^{-1}$ of $\mathrm{N}, \mathrm{P}_{2} \mathrm{O}_{5}$ and $\mathrm{K}_{2} \mathrm{O}$ respectively was carried out when sowing, using as a source the mineral fertilisers urea, single superphosphate and potassium chloride. Twenty days after sowing, $140 \mathrm{~g}$ and $45 \mathrm{~kg} \mathrm{ha}^{-1}$ of $\mathrm{N}$ and $\mathrm{K}_{2} \mathrm{O}$ respectively were applied as cover. 


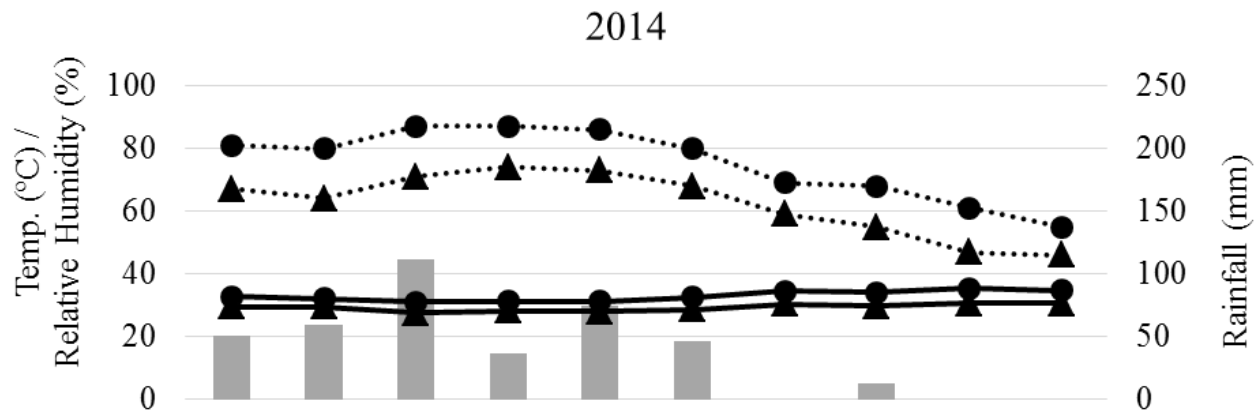

2015

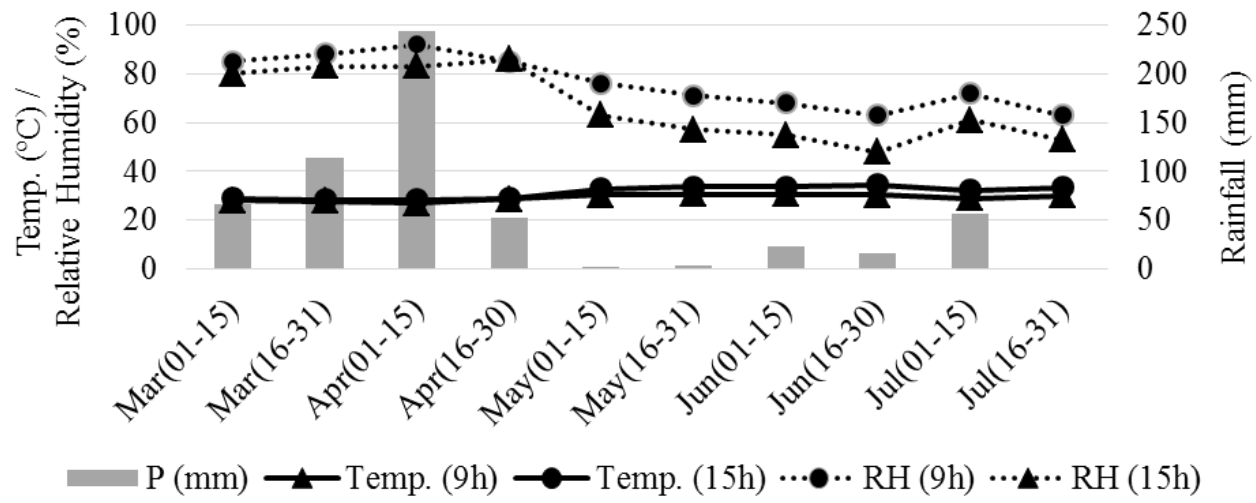

Source: Weather station on the Curu Valley Experimental Farm of the Federal University of Ceará. RH: relative humidity; P: accumulated rainfall.

Figure 1. Mean values for temperature, relative humidity and accumulated rainfall for March to July of 2014 and 2015, in Pentecoste, CE.

Table 1. Physico-chemical conditions of the soil at depths of $0-20 \mathrm{~cm}$ in the experimental area of the Vale do Curu Farm, Pentecoste, CE, Brazil.

\begin{tabular}{|c|c|c|c|c|c|c|c|c|}
\hline Year & $\mathrm{Ca}^{2+}$ & $\mathrm{Mg}^{2+}$ & $\mathrm{Na}^{+}$ & $\mathrm{K}^{+}$ & $\mathrm{H}^{+}+\mathrm{Al}^{3+}$ & $\mathrm{Al}^{3+}$ & $\mathrm{S}$ & $\mathrm{T}$ \\
\hline 2014 & 6.0 & 2.5 & 0.34 & 0.68 & 0.99 & 0.10 & 9.5 & 10.5 \\
\hline \multirow[t]{2}{*}{2015} & 6.5 & 3.0 & 0.40 & 0.69 & 0.83 & 0.15 & 10.6 & 11.6 \\
\hline & V & $\mathrm{m}$ & $\mathrm{C}$ & $\mathrm{N}$ & $\mathrm{OM}$ & Assimilated P & $\mathrm{C} / \mathrm{N}$ & ESP \\
\hline \multicolumn{9}{|c|}{--- \% --- } \\
\hline 2014 & 90 & 1 & 8.52 & 0.89 & 14.69 & 0.098 & 10 & 3 \\
\hline \multirow[t]{3}{*}{2015} & 91 & 1 & 5.70 & 0.58 & 9.83 & 0.150 & 10 & 3 \\
\hline & $\mathrm{BD}$ & $\mathrm{pH}$ & $\mathrm{EC}$ & $\begin{array}{c}\text { Course } \\
\text { Sand }\end{array}$ & Fine Sand & Silt & Clay. & $\begin{array}{c}\text { Natural } \\
\text { Clay }\end{array}$ \\
\hline & $\mathrm{g} \mathrm{cm}^{-3}$ & $\mathrm{H}_{2} \mathrm{O}$ & $\mathrm{dS} \mathrm{m}^{-1}$ & & ----------. & $\mathrm{g} \mathrm{kg}^{-1}$ & ----- & \\
\hline 2014 & 1.34 & 7.0 & 0.84 & 13 & 572 & 280 & 135 & 85 \\
\hline 2015 & 1.43 & 7.1 & 0.70 & 12 & 588 & 281 & 119 & 82 \\
\hline
\end{tabular}

$\mathrm{S}$ - sum of bases; $\mathrm{T}$ - potential cation exchange capacity; $\mathrm{V}$ - base saturation; $\mathrm{m}$ - aluminium saturation; OM - organic matter; ESP - exchangeable sodium percentage; BD - bulk density; EC - electrical conductivity. Source: Soil/Water Laboratory, Department of Soil Science, UFC; Fundação Cearense de Meteorologia e Recursos Hídricos - FUNCEME.

To apply the treatments, foliar fertilisation with potassium silicate $\left(\mathrm{Abrafol}^{\odot}\right.$ : $12 \% \mathrm{SiO}_{2} ; 12 \%$ $\mathrm{K}_{2} \mathrm{O}$ ) was carried out at doses of 500,1000 and $1500 \mathrm{~mL} \mathrm{ha}{ }^{-1}$. The applications were made using a backpack spray $(20 \mathrm{~L})$ with a piston pump, and a flat fan nozzle with a flow rate of $19 \mathrm{~L} \mathrm{~h}^{-1}$ attached to a drift guard in order to avoid influencing the remaining lots, including the control (with no 
application). Assist ${ }^{\odot}$ surfactant was also used at a concentration of $5 \%$ of the solution volume $\left(100 \mathrm{~L} \mathrm{ha}^{-1}\right)$.

In the first crop cycle (2014), silicate fertilisation was carried out when the plants were between stages V7 and V9 (seven to nine completely expanded leaves), which occurred 30 days after sowing (DAS). In the second cycle (2015), the fertilisation was carried out both at an earlier stage (V4 to V6) at 20 DAS, and at the same time as in the previous cycle, V7 and V9, which occurred at 25 DAS.

The experimental design was in randomised blocks, with four replications in a scheme of split-subdivided lots $(2 \times 4 \times 4)$ : two cultivars, four silicon levels (including the plot with no application) and four harvest periods. Harvesting was at 30, 37, 44 and 51 days after full bloom (over $50 \%$ of the plants in the plot having an expanded inflorescence), with the cultivars reaching this stage at different times, 57 and 64 days after sowing, for BRS 511 and BRS 506 respectively.

Each plot $\left(14 \mathrm{~m}^{2}\right)$ consisted of four five-meter rows containing 40 plants in each row $\left(8 \mathrm{pl} \mathrm{m}^{-1}\right)$, spaced $0.70 \mathrm{~m}$ apart, with the two central rows taken as the working area of the plot.

To analyse seed quality, three panicles were collected per plot with the help of pruning shears, cutting at the insertion of the flag leaf; these were taken to the Laboratory for Seed Analysis (UFC) for the panicles to be weighed and the seeds extracted and counted.

The seeds were subjected to the following analyses: water content (WC) - by the oven method at $105^{\circ} \mathrm{C}\left( \pm 2^{\circ} \mathrm{C}\right)$ for $24 \mathrm{~h}$, using 50 seeds; thousand seed weight (TSW) - using eight replications of 100 seeds, multiplying the mean value by 10 when the coefficient of variation was lower than $4 \%$ (BRASIL, 2009): the thousand seed weight was only carried out for the 2014 cycle due to the smaller quantity of seeds the following year as a result of the high index of bird predation, which had not been seen the previous year: in 2015 therefore, four replications of 100 seeds were weighed, and the mean value taken as the final value for the hundred seed weight (HSW); germination - four replications of 50 seeds from each plot were placed between germitest paper towels, moistened to three times the weight of the dry paper, and placed in a bench germinator set to $25^{\circ} \mathrm{C}$. The counts were taken on the fourth day (first count - FC) and tenth day (final germination - G) after sowing (BRASIL, 2009); Germination Speed Index (GSI) - calculated according to the formula by Maguire (1962): $\mathrm{GSI}=\mathrm{G} 1 / \mathrm{N} 1+\mathrm{G} 2 / \mathrm{N} 2+\ldots+\mathrm{Gn} / \mathrm{Nn}$, where $\mathrm{G} 1, \mathrm{G} 2$, $\mathrm{Gn}=$ number of seedlings at the first, second, up to the last count, and $\mathrm{N} 1, \mathrm{~N} 2$ and $\mathrm{Nn}=$ number of days of the first, second, up to the last count; accelerated ageing test (AA) - four replications of 50 seeds were placed on aluminium screens inserted into gerbox plastic boxes, containing $40 \mathrm{~mL}$ of distilled water, and placed in a Biochemical Oxygen Demand (BOD) chamber for 96 hours at $41^{\circ} \mathrm{C}$ (VAZQUEZ; BERTOLIN; SPEGIORIN, 2011), followed by the germination test, when the seedlings were counted four days after sowing; and seedling size - 20 seedlings from the germination test were measured to determine the mean total seedling length (SL).

With data for the variables GSI, SL/2014 and $\mathrm{AA} / 2015$ that met the assumptions of normality and homoscedasticity, an analysis of variance (ANOVA) was performed using Tukey's test $(5 \%)$ to compare the mean values for the two cultivars; where the F-test was significant, the polynomial regression was studied to analyse the doses of silicon and the harvest periods. For the other variables, the non-parametric Kruscal-Wallis test $(5 \%)$ was performed. The GSI variable for both years was analysed with data transformed by the Box-Cox system, which allowed fitting the data for ANOVA.

\section{RESULTS AND DISCUSSION}

The seeds produced in cycle 1 (2014) showed a variation in water content of between $13 \%$ and $19 \%$, with no differences $(\mathrm{p}>0.05)$ due to variety or to fertilisation with the potassium silicate. In this cycle, a significant difference was found between the mean values for water content $(p \leq 0.05)$ for the factor Harvest Period. At 30 days after full bloom, the seeds displayed 19\%, dropping to $13 \%$ the following week, i.e. 37 days after full bloom (Table 2). From this point on (37 days), the seeds seem to have ended dehydration due to the maturation process, thereby starting to be conditioned only by the environment in their search for hygroscopic balance.

In cycle 2 (2015), the water content of the seeds was already balanced from the first harvest, with one difference to the previous cycle: the seeds displayed lower values for water content, between $7 \%$ and $9 \%$, irrespective of the sources of variation in the study (Table 3). Climate fluctuations occurring during seed maturation do not seem significant enough to justify this difference in water content between cycles 1 and 2 . The response has more to do with the panicles harvested in the second cycle having far fewer seeds than in the previous year; in 2015 , there was severe bird predation and seeds were only found at the apex of the most external panicles, i.e. there were few seeds in direct contact with the environment, causing greater desiccation.

The reduction in water content occurred while still in the field, remaining at an ideal range for harvest until 51 days after full bloom. In the case of commercial production, artificial drying, which raises the cost of production in regions of high humidity, would not be necessary, a great advantage 
for seed production in the semi-arid region. Ullmann et al. (2015) verified high physiological quality in seeds of sweet sorghum with artificial drying at a temperature of $40^{\circ} \mathrm{C}$. In the present study, in the final month of the crop cycle, the air temperature reached a range of $35^{\circ} \mathrm{C}$ to $37^{\circ} \mathrm{C}$ (Figure 1), which provided for adequate drying of the seeds while still in the field.

The varieties also differed $(p \leq 0.05)$ for thousand seed weight, in addition to the harvest periods; BRS 511 presented on average $1.4 \mathrm{~g}$ more compared to BRS 506 (Table 2). In the following cycle, BRS 511 maintained the heavier seeds, as evidenced by the hundred seed weight (Table 3 ).
This difference in weight between the two cultivars however, does not represent any intrinsic superiority for the BRS 511 variety. Kirchner et al. (2014) emphasise that physiological quality goes beyond the thousand seed weight. In the work of those authors, carried out in Santa Maria in the state of Rio Grande do Sul, a region with contrasting conditions to those of the semi-arid region, it can be seen that seeds produced and subjected to artificial drying so as to reach a moisture content of $12-13 \%$, obtained 19.4 to $20 \mathrm{~g} / 1000$ seeds. In the present study, seeds produced in the semi-arid region of Ceará under natural drying (12.9\% at 37 days after blooming), obtained on average $20.8 \mathrm{~g}$ during the 2014 cycle.

Table 2. Water content (WC), first germination count (FC), final germination (G), accelerated ageing test (AA) and thousand seed weight (TSW) in two cultivars of sweet sorghum grown between March and July of 2014 and submitted to different levels of silicate fertilisation and harvest periods.

\begin{tabular}{|c|c|c|c|c|c|}
\hline \multirow{2}{*}{$\begin{array}{r}\text { Source of Variation } \\
\text { and Level }\end{array}$} & \multicolumn{5}{|c|}{ Cycle 1 (2014) } \\
\hline & WC & $\mathrm{FC}$ & $\mathrm{G}$ & $\mathrm{AA}$ & TSW \\
\hline VARIETY & & -1------- \% & 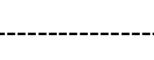 & & --- g --- \\
\hline BRS 506 & $13 \mathrm{a}$ & $66 \mathrm{a}$ & $91 \mathrm{a}$ & $90 \mathrm{a}$ & $20.3 \mathrm{~b}$ \\
\hline BRS 511 & $15 \mathrm{a}$ & $61 \mathrm{a}$ & $91 \mathrm{a}$ & $85 \mathrm{~b}$ & $21.7 \mathrm{a}$ \\
\hline K-W (p) & 0.0739 & 0.2228 & 0.2517 & $3.14 \times 10^{-5}$ & $8.52 \times 10^{-7}$ \\
\hline \multicolumn{6}{|l|}{$\mathrm{K}_{2} \mathrm{SiO}_{3}\left(\mathrm{~mL} \mathrm{ha}^{-1}\right)$} \\
\hline 0 (control) & 14. a & $62 \mathrm{a}$ & $90 \mathrm{a}$ & 88 a & $21.0 \mathrm{a}$ \\
\hline 500 & $15 \mathrm{a}$ & $67 \mathrm{a}$ & 92 a & $87 \mathrm{a}$ & $21.0 \mathrm{a}$ \\
\hline 1000 & $14 \mathrm{a}$ & $65 \mathrm{a}$ & $91 \mathrm{a}$ & $87 \mathrm{a}$ & $21.2 \mathrm{a}$ \\
\hline 1500 & $14 \mathrm{a}$ & $60 \mathrm{a}$ & $90 \mathrm{a}$ & $87 \mathrm{a}$ & $21.1 \mathrm{a}$ \\
\hline $\mathrm{K}-\mathrm{W}(\mathrm{p})$ & 0.8654 & 0.7326 & 0.9252 & 0.9114 & 0.9897 \\
\hline \multicolumn{6}{|l|}{ HARVEST (DAB) } \\
\hline 30 & $19 \mathrm{a}$ & $24 \mathrm{c}$ & $80 \mathrm{~b}$ & 89 a & $21.0 \mathrm{ab}$ \\
\hline 37 & $13 \mathrm{~b}$ & $53 \mathrm{~b}$ & $94 \mathrm{a}$ & $85 \mathrm{a}$ & $20.8 \mathrm{~b}$ \\
\hline 44 & $11 \mathrm{c}$ & 89 a & $95 \mathrm{a}$ & 88 a & $20.6 \mathrm{~b}$ \\
\hline 51 & $14 \mathrm{~b}$ & $88 \mathrm{a}$ & $94 \mathrm{a}$ & $87 \mathrm{a}$ & $21.8 \mathrm{a}$ \\
\hline $\mathrm{K}-\mathrm{W}(\mathrm{p})$ & $1.77 \times 10^{-18}$ & $9.16 \times 10^{-19}$ & $9.4 \times 10^{-13}$ & 0.3949 & 0.0119 \\
\hline CV (\%) & 26.6 & 48.8 & 10.2 & 8.1 & 7.73 \\
\hline
\end{tabular}

Days after full bloom (DAB); Mean values followed by the same letters in a column do not differ by non-parametric Kruskal-Wallis test $(\mathrm{K}-\mathrm{W})$, with multiple pair-wise comparisons when the $\mathrm{p}$-value $\leq 0.05$ at $5 \%$ significance. 
Table 3. Water content (WC), first germination count (FC), final germination (G), accelerated ageing test (AA) and hundred seed weight (HSW) in two cultivars of sweet sorghum grown between March and July of 2015 and subjected to different levels of silicate fertilisation and harvest periods.

\begin{tabular}{|c|c|c|c|c|c|}
\hline \multirow{2}{*}{$\begin{array}{r}\text { Source of Variation } \\
\text { and Level }\end{array}$} & \multicolumn{5}{|c|}{ Cycle 2 (2015) } \\
\hline & WC & $\mathrm{FC}$ & G & AA* & HSW \\
\hline VARIETY & \multicolumn{4}{|c|}{ 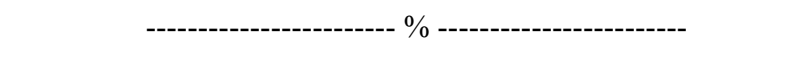 } & --- g --- \\
\hline BRS 506 & $8.0 \mathrm{a}$ & $49 \mathrm{~b}$ & 92 a & $71 \mathrm{a}$ & $1.91 \mathrm{~b}$ \\
\hline BRS 511 & $7.0 \mathrm{a}$ & 56 a & 93 a & 65 a & $2.10 \mathrm{a}$ \\
\hline K-W (p) & 0.1001 & 0.0058 & 0.2041 & - & $2.35 \times 10^{-14}$ \\
\hline \multicolumn{6}{|l|}{$\mathrm{K}_{2} \mathrm{SiO}_{3}\left(\mathrm{~mL} \mathrm{ha}^{-1}\right)$} \\
\hline 0 (control) & $7.0 \mathrm{a}$ & 63 a & 93 a & - & $1.99 \mathrm{a}$ \\
\hline 500 & $7.0 \mathrm{a}$ & $51 \mathrm{~b}$ & 93 a & - & $2.02 \mathrm{a}$ \\
\hline 1000 & $8.0 \mathrm{a}$ & $50 \mathrm{~b}$ & 90 a & - & $1.99 \mathrm{a}$ \\
\hline 1500 & $7.0 \mathrm{a}$ & $47 \mathrm{~b}$ & 94 a & - & $2.01 \mathrm{a}$ \\
\hline K-W (p) & 0.9216 & 0.0038 & 0.7586 & - & 0.7811 \\
\hline \multicolumn{6}{|l|}{ HARVEST (DAB) } \\
\hline 30 & $9.0 \mathrm{a}$ & $49 \mathrm{a}$ & 94 a & - & $1.99 \mathrm{a}$ \\
\hline 37 & $7.0 \mathrm{~b}$ & $51 \mathrm{a}$ & 94 a & - & $2.00 \mathrm{a}$ \\
\hline 44 & $7.0 \mathrm{~b}$ & $55 \mathrm{a}$ & 93 a & - & $2.01 \mathrm{a}$ \\
\hline 51 & $7.0 \mathrm{~b}$ & 56 a & 88 a & - & $2.02 \mathrm{a}$ \\
\hline $\mathrm{K}-\mathrm{W}(\mathrm{p})$ & $7.4 \times 10^{-7}$ & 0.0555 & 0.2689 & - & 0.8812 \\
\hline CV (\%) & 20.9 & 30.2 & 8.5 & $\begin{array}{c}23.8 \\
\text { (plot) }\end{array}$ & 7.0 \\
\hline
\end{tabular}

Days after full bloom (DAB); Mean values followed by the same letters in a column do not differ by non-parametric Kruskal-Wallis test $(\mathrm{K}-\mathrm{W})$, with multiple pair-wise comparisons when the p-value $\leq 0.05$ at $5 \%$ significance, *with the exception of AA analysed by Tukey's test (5\%).

The germination test attained average values of $91 \%$ to $93 \%$ for the varieties under study (Tables 2 and 3). This range of germination was similar to that found by Ullmann et al. (2015), where the seeds of the BRS 506 variety of sweet sorghum reached a value for germination of $88 \%$ to $94 \%$, indicating high physiological quality for the different conditions of the study. In a study carried out in Iran with other varieties (Rio, Keller, Sofra and Soave), germination was no greater than $71 \%$ in the standard germination test (ALMODARES; HADI; DOSTI, 2007), far less than the results in the present work.

It can be seen in Table 2 that at 37 days after full bloom the seeds were at maximum germination potential, remaining at this level until 51 DAB. In 2015, the maximum percentage was already established by 30 DAB (94\%). This percentage of germination is satisfactory according to the minimum requirements of the Brazilian Association of Seeds and Seedlings, which are $70 \%$ for basic seeds and $80 \%$ for the other categories (ABRASEM, 2013).

For the ideal harvest period in the BRS 506 and BRS 511 cultivars, it was found that at 37 days after blooming, germination was already at its maximum potential. The first germination count showed that maximum potential was reached at 44 days after blooming (Table 2), but mathematical adjustment of the Germination Speed Index, which could be evaluated parametrically, gave a more precise result. The analysis of variance revealed a significant interaction between the factors Variety and Harvest $(\mathrm{p} \leq 0.01)$, with adjustment of the data by the quadratic polynomial model for both varieties (Figure 2A). 


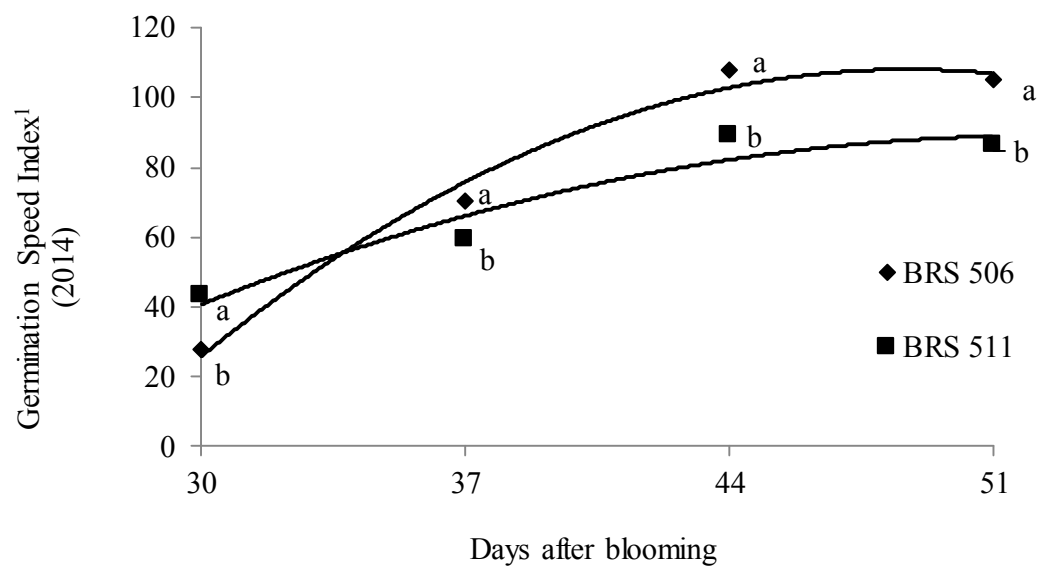

A

$\begin{array}{cc}\text { BRS } 506=-0.2333^{* *} \mathrm{x}^{2}+22.753^{* *} \mathrm{x}-446.65^{* *} & \text { BRS } 511=-0.0946^{* *} \mathrm{x}^{2}+9.9553^{* *} \mathrm{x}-172.73^{* *} \\ \mathrm{R}^{2}=0.9851^{* *} & \mathrm{R}^{2}=0.9257^{* *}\end{array}$

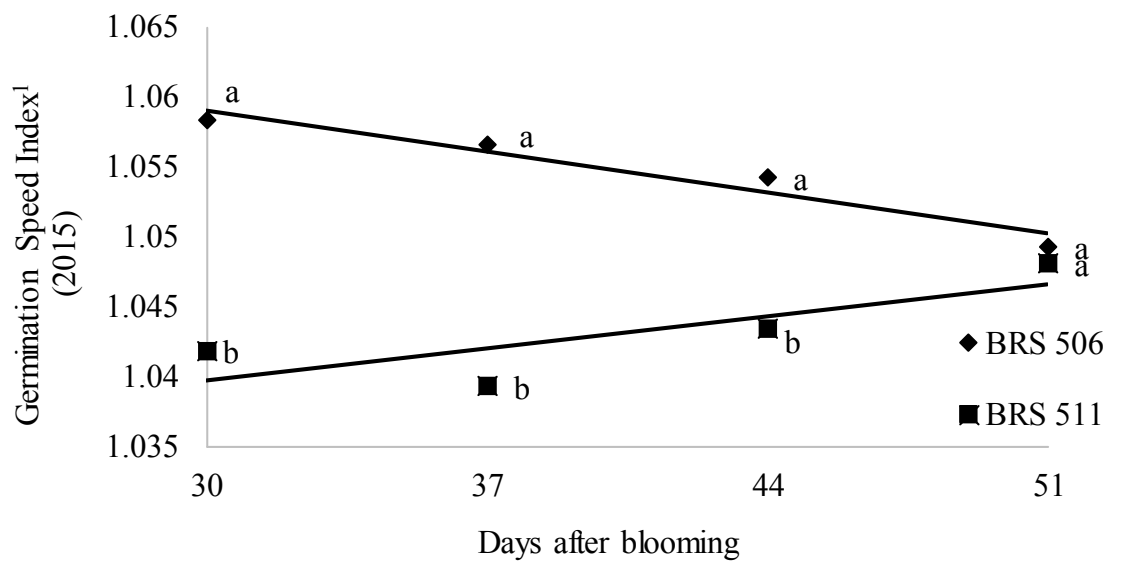

BRS $506=-0.0004 * * \mathrm{x}+1.0717 * *$

$$
\mathrm{R}^{2}=0.9429 * *
$$

BRS $511=0.0003 * \mathrm{x}+1.03 * *$

$$
\mathrm{R}^{2}=0.6367^{*}
$$

${ }^{1}$ Scale with values transformed by the Box-Cox system $(\lambda=2.0454$ (graph A); $\lambda=-0.8333$ (graph B)). ${ }^{* *}$ significant at $1 \%$ by F-test in the regression analysis. Superscript letters compare varieties within each harvest period and indicate statistical difference by Tukey's test at $5 \%$.

Figure 2. Germination speed index (GSI) in seeds of two varieties of sweet sorghum for harvest period, in the 2014 (A) and 2015 (B) cycles.

The germination speed index in seeds of the BRS 506 variety was greater than in the BRS 511 (Figure 2A); this was repeated in the second cycle until 44 DAB (Figure 2B). According to the mathematical fit $(p \leq 0.01)$ in the first crop cycle, the BRS 506 variety reached maximum value for germination speed at 49 days after full bloom; for BRS 511, this maximum value was reached at 53 DAB (Figure 2A).

In 2015, there was contrasting behaviour between the varieties in relation to germination speed. This time adjustment of the data had a linear pattern, with different levels of significance between the varieties, $\mathrm{p} \leq 0.01$ and $\mathrm{p} \leq 0.05$ respectively for BRS 506 and BRS 511. There was no peak in speed as in the previous year; the BRS 506 variety lost germination speed over time, revealing a steep pattern for speed from the first evaluations, while with the BRS 511 variety, the GSI increased up to
$51 \mathrm{DAB}$, reaching the BRS 506 indices only at the last evaluation (Figure 2B). The more intense differences in climate and biotic interaction (predation and infections) that year probably promoted divergent behaviour between the varieties, since each genotype reacts to the weather in a specific way.

One important evaluation of seed vigour is the accelerated ageing test. In the first year of growth, the BRS 506 cultivar did not suffer a reduction in germination due to subjected stress; the seeds maintained the $90 \%$ germination obtained in the germination test (Table 2). The BRS 511 cultivar however, despite not having suffered an expressive reduction in germination after accelerated ageing, displayed a decrease in this variable, differing significantly from BRS 506. There was no influence on this variable from the other factors under study.

In the following cycle (2015), as the data met 
the statistical assumptions, the variable AA was evaluated parametrically, giving new results. This time the varieties did not differ $(p>0.05)$ when compared independently, and showed a loss in germination percentage (Table 3). Furthermore, the analysis of variance indicated a significant triple interaction $(\mathrm{p} \leq 0.01)$ between the factors. The respective breakdowns are shown in Figures 3, 4 and 5.

Figure 3 shows the breakdown between the lots (varieties) and the sub-lots (doses), revealing a significant fit for the cubic model representing the actual behaviour of the data $\left(R^{2}=1\right)$ and showing a distinct effect between the varieties.
In the BRS 506 variety, the minimum and maximum peaks presented by the regression adjustment $(\mathrm{p} \leq 0.01)$ were for 538 and $1367 \mathrm{~mL} \mathrm{ha}^{-1}$ potassium silicate respectively. Whereas in the BRS 511 variety, the maximum peak of the curve was for $476 \mathrm{~mL} \mathrm{ha}{ }^{-1}$ and the minimum for $857 \mathrm{~mL} \mathrm{ha}^{-1}(\mathrm{p} \leq 0.05)$, with an increase in the percentage value starting from this dose. Always considering the best results for germination percentage, the dose of $1500 \mathrm{~mL} \mathrm{ha}^{-1}$ potassium silicate promoted an increase in vigour in BRS 511, while in BRS 506, this value was $1367 \mathrm{~mL} \mathrm{ha}^{-1}$, with the peak for germination representing maximum germination (Figure 3).

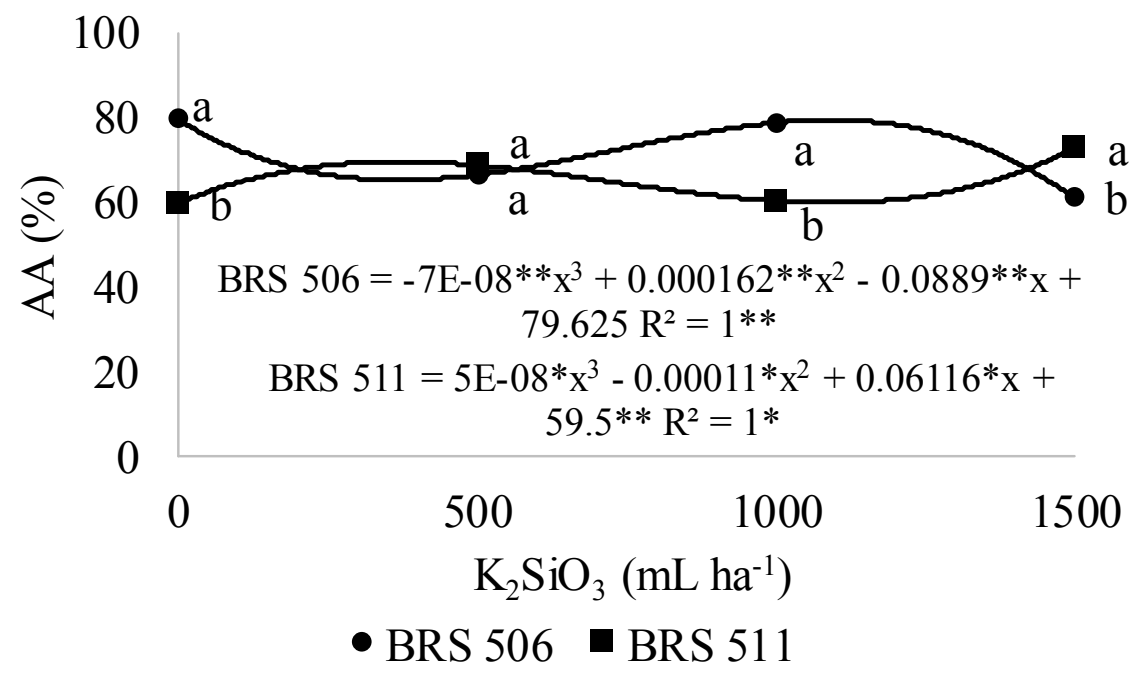

\begin{abstract}
** significant at $1 \%$ and $* 5 \%$ by F-test in the regression analysis. Superscript letters compare varieties within each harvest period and indicate statistical difference by Tukey's test at $5 \%$.
\end{abstract}

Figure 3. Accelerated Ageing Test (AA) in seeds of two varieties of sweet sorghum for potassium silicate fertilisation.

Silicate fertilisers are commonly associated with plant protection against herbivory, infectious agents and environmental stress (HAYNES, 2014; GUNTZER; KELLER; MEUNIER, 2012), and avoid the expenditure of energy from plant metabolism on such protection (secondary metabolism), which is thereby better utilised in processes for the accumulation of primary metabolites, essential for the development of the panicles and seeds (SOUSA; KORNDÖRFER; WANGEN, 2010).

According to the literature, under other growing conditions, specific fertilisation techniques have proved to be important in different crops. Tavares et al. (2014) studied the isolated effect of silicon on yield and seed quality in wheat, when, despite finding no effect on seed quality, an increase in yield was seen. It is important to note that in the above-mentioned work the silicon was incorporated into the soil under greenhouse conditions. In addition to grasses, a family known to be more responsive to silicon, legumes have also been tested for this specific type of fertilisation. In the soybean, foliar fertilisation with silicate, using silicon dioxide in doses of 40 and $50 \mathrm{~kg} \mathrm{ha}^{-1}$, promoted the production of seeds of better physiological quality (HARTER; BARROS, 2011).

Despite there being a statistically significant effect on vigour in the seeds of sweet sorghum from fertilisation with potassium silicate, there was no stable biological relationship, demonstrating the need for more research in the same area, and if possible in a more specific way, to answer other questions such as the type and number of applications, the different doses, and the phenological stage of the plant which might be most favourable to the technique. In this way, new opportunities would be available for further scientific investigation, which would seek to achieve more concise and satisfactory results regarding complementary fertilisation with silicate in sweet sorghum.

For harvest period, vigour represented by the accelerated ageing test was at maximum at 42 days after blooming in the BRS 511 variety $(\mathrm{p} \leq 0.05)$, reaching a value for post-stress germination of $70 \%$, as can be seen in Figure 4. In the BRS 506 variety, the mathematical fit $(\mathrm{p} \leq 0.01)$ showed a decrease for 
up to 41 days after blooming, with a resumption of germination potential after this period. This variety was probably more affected by the lack of rainfall between day 30 and day 40 of maturation; the absence of precipitation precisely during this period
(May 2015) can be seen in Figure 1. This may have contributed to the slight fall in vigour compared to BRS 511, which maintained the increase in vigour until reaching the point of physiological maturity (42 DAB) and entering the stage of field storage.

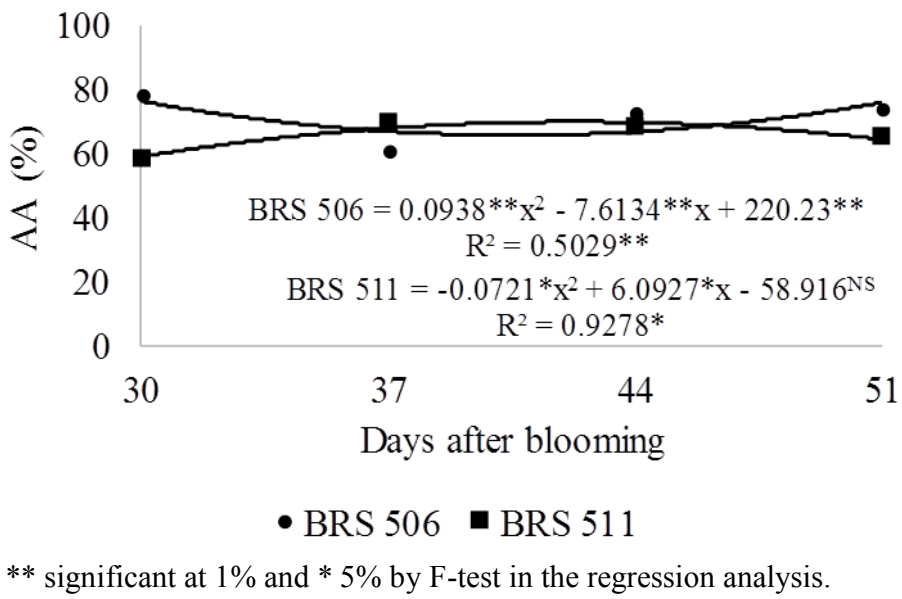

Figure 4. Accelerated Ageing Test (AA) in two varieties of sweet sorghum for harvest period.

With the return of the rainfall in June (light rains at the end of the 2015 season) (Figure 1), the seeds of BRS 506 had regained vigour by 51 DAB. These results demonstrate the good adaptability of the BRS 511 variety to the conditions of irregular rainfall characteristic of semi-arid conditions.
With the association between silicate level and harvest period, it can be seen that there was a linear upward pattern $(p \leq 0.01)$ only in seeds produced by plants treated with $1500 \mathrm{~mL}$ of silicate; at the other levels there was no significant fit with regression (Figure 5A).
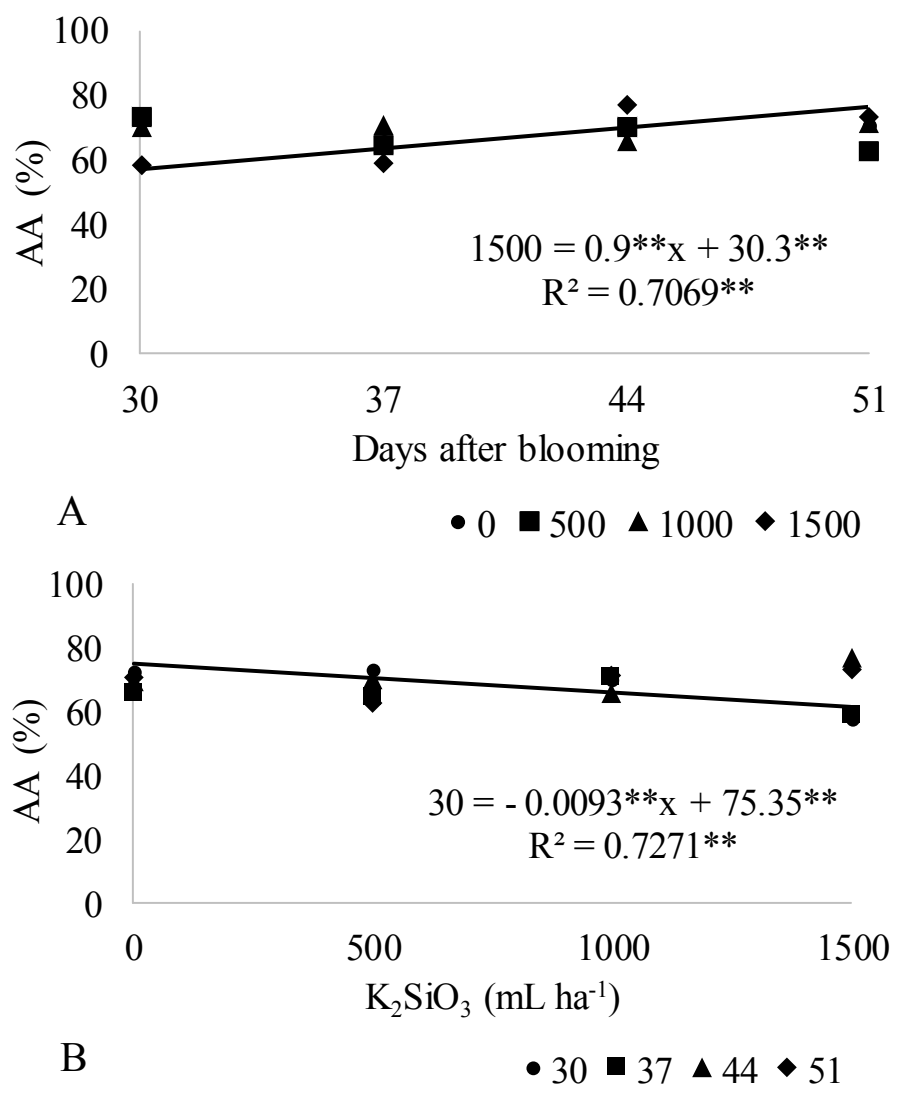

**significant at $1 \%$ by $\mathrm{F}$-test in the regression analysis.

Figure 5. Breakdown of the accelerated ageing test (AA) for harvest period at each level of potassium silicate (A) and for the study of silicate dose for each harvest period (B). 
It can therefore be seen that this dose promoted better uniformity of the seed maturation process, confirming the data discussed above and presented in Figure 3. At the silicate levels under study for each harvest period (Figure 5B), it was not possible to diagnose a satisfactory effect from complementary fertilisation specifically, there being no effect for seeds harvested from 37 DAB. There was even a linear decrease $(p \leq 0.01)$ in vigour due to the complementary fertilisation at $30 \mathrm{DAB}$, the only period that was significant between doses (Figure 5B).

Analysing seedling length, no interaction effect was seen, and the factors could only be

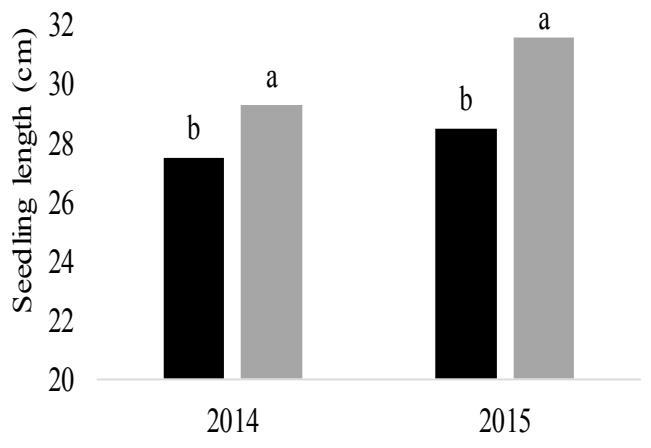

-BRS 506 BRS 511 analysed independently. In both crop cycles, the BRS 511 variety produced larger seedlings than BRS 506 $(\mathrm{p} \leq 0.05)$ (Figure 6A). In general, for both varieties in the first cycle (2014), quadratic behaviour $(p \leq 0.01)$ in growth was observed throughout the maturation process, with an upward curve from $23 \mathrm{DAB}$ to the maximum at $51 \mathrm{DAB}$ (end of the experiment). In the following cycle there was no mathematical fit with respect to harvest period, the length of the seedlings remained stable throughout (Figure 6B), probably due to the greater rainfall during the season bringing benefits for plant development.

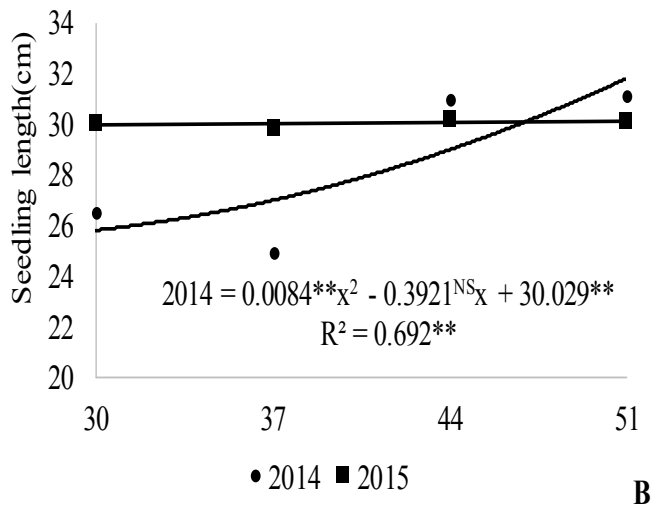

**significant at $1 \%$ and ${ }^{\mathrm{NS}}$ no significant by F-test in the regression analysis. Superscript letters compare varieties and indicate statistical difference by Tukey's test at $5 \%$.

Figure 6. Seedling length from the germination test in seeds of sweet sorghum grown in 2014 and 2015, for variety and harvest period.

In general, the seeds displayed better conditions of germination and vigour when harvested between 49 and 53 days after full bloom in a semi-arid environment. In research by Andrade and Oliveira (1988), in Sete Lagoas, Minas Gerais, one of the few studies into sweet sorghum, higher values for germination percentage and vigour were found at 35 to 44 days after full bloom, at which point the seeds contained $30 \%$ moisture, with the germination percentage of only $70 \%$ being much lower than that found in the present study, demonstrating a need for artificial drying.

Therefore, even with the later maturation ( $\sim 50 \mathrm{DAB})$, the seeds produced in the present study were already in the condition of full storage (low humidity, and maximum germination and vigour), or of immediate usage, at this maturation stage, without the need for any technological intervention. As an additional management technique for growing sweet sorghum with a view to better seed development, foliar fertilisation with potassium silicate proved to be very promising, with the proviso that there is a need for further specific research into the technique.

\section{CONCLUSIONS}

Seeds of the BRS 506 and BRS 511 cultivars of sweet sorghum produced in the semi-arid region of Ceará, display suitable physiological quality for marketing, reaching maximum germination and vigour between 49 and 53 days after full bloom. It was not possible to define exactly the effect on seed quality of foliar fertilisation with silicate; the increase in vigour diagnosed by the accelerated ageing test reveals the need for further investigation to define the type and dose of application.

\section{REFERENCES}

ALMODARES, A.; HADI, M. R.; DOSTI, B. Effects of salt stress on germination percentage and seedlings growth in sweet sorghum cultivars. Journal of Biological Science, Dubai, v. 7, n. 8, p. 1492-1495, 2007.

ANDRADE, R. V.; OLIVEIRA, A. C. Maturação fisiológica do colmo e de sementes de sorgo sacarino. Revista Brasileira de Sementes, Londrina, 
v. 10 , n. 3, p. 19-31, 1988 .

ARAÚJO, E. F. et al. Maturação de sementes de milho-doce - grupo super doce. Revista Brasileira de Sementes, Londrina, v. 28, n. 2, p. 69-76, 2006.

ASSOCIAÇÃO BRASILEIRA DE SEMENTES E MUDAS - ABRASEM. Instrução Normativa, $\mathrm{n}^{\circ}$ 45, de 17 de Setembro de 2013. 38 p. Ministério da Agricultura, Pecuária e Abastecimento. Disponível em: $\quad<$ http://www.abrasem.com.br/wp-content/ uploads $/ 2012 / 10 /$ Instru $\%$ C3\%A7\%C3\%A3oNormativa-n $\% \mathrm{C} 2 \% \mathrm{BA}-45$-de-17-de-Setembro-de2013-Padr\%C3\%B5es-de-Identidade-e-QualiidadeProd-e-Comerc-de-Sementes-Grandes-CulturasRepublica\%C3\%A7\%C3\%A3o-DOU-20.09.13.pdf $>$. Acesso em: 06 fev. 2017.

BARBOSA, N. C. et al. Formas de aplicação de silicato de cálcio e magnésio na cultura do sorgo em neossolo quartzarênico de cerrado. Pesquisa Agropecuária Tropical, Goiânia, v. 38, n. 4, p. 290-296, 2008.

BLUM, A. Sorghum physiology. In: Nguyen H. T.; Blum A. (Eds.). Physiology and biotechnology integration for plant breeding. New York: Marcel Dekker, 2004. cap. 4, p. 119-187.

BRASIL. Ministério da Agricultura, Pecuária e Abastecimento. Regras para análise de sementes. Ministério da Agricultura, Pecuária e Abastecimento. Secretaria de Defesa Agropecuária. Brasília: MAPA/ ACS, 2009. 395 p.

COElHO, A. M. Adubação. In: MAY, A. et al. (Eds.). Sistema agroindustrial do sorgo sacarino no Brasil e a participação público-privada: oportunidades, perspectivas e desafios. Sete Lagoas: Embrapa Milho e Sorgo, 2012. cap. 5, p. 42-50, 2012. (Documentos 139).

EMPRESA BRASILEIRA DE PESQUISA AGROPECUÁRIA - EMBRAPA. BRS 506: o sorgo sacarino mais testado e plantado no Brasil. Embrapa Milho e Sorgo, 2012a. Disponível em: $<$ http://www.infoteca.cnptia.embrapa.br/handle/ doc/937340 >. Acesso em: 10 ago. 2016.

EMPRESA BRASILEIRA DE PESQUISA AGROPECUÁRIA - EMBRAPA. BRS 511: o sorgo sacarino com alto potencial de colmos. Embrapa Milho e Sorgo, 2012b. Disponível em: <http:// www.infoteca.cnptia.embrapa.br/handle/ doc/937343>. Acesso em: 10 ago. 2016.

GIACOMINI, I. et al. Uso potencial de sorgo sacarino para a produção de etanol no estado do Tocantins. Revista Agrogeoambiental, Pouso Alegre, v. 5, n. 3, p. 73-82, 2013.
GUNTZER, F.; KELLER, C.; MEUNIER, J-D. Benefts of plant silicon for crops: a review. Agronomy Sustainable Development, Paris, v. 32, n. 1, p. 201-213, 2012.

HARTER, F. S.; BARros, A. C. S. A. Cálcio e silício na produção e qualidade de sementes de soja. Revista Brasileira de Sementes, Londrina, v. 33, n. 1, p. 54-60, 2011.

HAYNES, R. J. A contemporary overview of silicon availability in agricultural soils. Journal of Plant Nutrition and Soil Science, Landau, v. 177, n. 6, p. 831-844, 2014

KIRCHNER, J. H. et al. Qualidade física, fisiológica e potencial produtivo de sementes de sorgo sacarino em Santa Maria, RS. Tecnologia e Ciência Agropecuária, João Pessoa, v. 8, n. 1, p. 29-34, 2014.

MAGUIRE, J. D. Speed of germination-aid in selection and evaluation for seedling emergence and vigor. Crop Science, Madison, v. 2, n. 1, p. 176-177, 1962.

MARCOS FILHO, J. Fisiologia de sementes de plantas cultivadas. 2. ed. Londrina, PR: ABRATES, 2015. 659 p.

MAY, A. et al. Sistema Embrapa de produção agroindustrial de sorgo sacarino para bioetanol: Sistema BRS 1G - Tecnologia qualidade Embrapa. Sete Lagoas, MG: Embrapa Milho e Sorgo, 2012. 118 p. (Documentos 139).

PEREIRA, H. S. et al. Silicon sources for rice crop. Scientia Agricola, Piracicaba, v. 61, n. 5, p. 522-528, 2004.

RATNAVATHI, C. V. et al. Sweet sorghum as feedstock for biofuel production: a review. Sugar Tech, New York, v. 13, n. 4, p. 399-407, 2011.

SOUSA, J. V. et al. Silicato de potássio via foliar no milho: fotossíntese, crescimento e produtividade. Bioscience Journal, Uberlândia, v. 26, n. 4, p. 502-513, 2010.

SOUSA, R. S. et al. Cytological aspects of the infection process of Pyricularia oryzae on leaves of wheat plants supplied with silicon. Tropical Plant Pathology, Brasília, v. 38, n. 6, p. 472-477, 2013.

SOUSA, R. T. X.; KORNDÖRFER, G. H.; WANGEN, D. R. B. Aproveitamento de silício proveniente de escória siderúrgica por cultivares de cana-de-açúcar. Bragantia, Campinas, v. 69, n. 3, p. 669-676, 2010. 
TAVARES, L. C. et al. Adubação silicatada em trigo: rendimento e qualidade de sementes. Revista de la Facultad de Agronomía, La Plata, v. 113, n. 1, p. 94-99, 2014.

ULLMANN, R. et al. Qualidade fisiológica das sementes de sorgo sacarino submetidas à secagem em diferentes condições de ar. Revista Brasileira de Engenharia Agrícola e Ambiental, Campina Grande, v. 19, n. 1, p. 64-69, 2015.

VAZQUEZ, G. H.; BERTOLIN, C. B.; SPEGIORIN, C. N. Testes de envelhecimento acelerado e de condutividade elétrica para avaliar a qualidade fisiológica de sementes de sorgo (Sorghum bicolor (L.) Moench). Revista Brasileira de Biociências, Porto Alegre, v. 9, n. 1, p. 18-24, 2011. 